\title{
Pesantren Walisanga Ende, Membangun Asa di Antara Kerasnya Alam: Pesantren Pertama Di Nusa Tenggara Timur (NTT)
}

\author{
Muhamad Murtadlo
}

\begin{abstract}
Abstrak
Kajian ini bertujuan untuk menjawab pertanyaan penelitian: bagaimana perkembangan dan adaptasi pesantren di Pulau Flores, Nusa Tenggara Timur; dan bagaimana peta tantangan yang dialami lemabaga pesantren di daerah itu? Kajian ini termasuk penelitian kualitatif dengan pendekatan studi kasus. Data dikumpulkan dengan tehnik pengamatan, wawancara dan studi dokumen. Selanjutnya data yang dikumpulkan dianalisa secara deskriptif.
\end{abstract}

Kata-kata kunci: Pesantren walisanga, Ende, Multikultural

\section{Pendahuluan}

Jam tangan menunjuk angka 15.20 Waktu Indonesia Tengah (WIT) ketika pesawat kami landing di Bandara $\mathrm{H}$ Aburusman Ende (Flores) Nusa Tenggara Timur. Perjalanan yang lumayan panjang dari Jakarta ke Ende dengan naik pesawat Lion yang harus singgah di Denpasar, Labuhan Bajo dan akhirnya ke Ende. Saat itu pesawat yang mendarat di Ende setiap harinya hanya tiga maskapai yaitu Garuda, Lion dan Air Asia. Saya memilih maskapai Lion Air, karena saya ingin mendapatkan penerbangan langsung dari Jakarta -Ende yang tidak perlu transit dan menginap di Denpasar. Pesawat Garuda saat itu kalo ingin mencapai Ende dari Jakarta dalam hari yang sama harus terbang dari Jakarta jam 23.00 malam dan harus bermalam di Bali. Baru pagi hari berikutnya meneruskan perjalanan Denpasar -Ende.
Sedangkan pesawat Lion dari Jakarta Ende bisa ditempuh dalam sehari, terbang dari Jakarta jam 8.20 pagi, sore sudahsampai ke tujuan.

Ende adalah kota kecil, layaknya kota kecamatan di Jawa, yang berada tepat di tengah Pulau Flores. Posisinya ada di sebelah selatan pulau itu. Akhirnya saya sampai juga ke Kota Ende, sebuah tempat yang lama mengundang rasa penasaranku untuk mengunjunginya, karena tempat itu Sukarno, Presiden RI pertama, pernah dibuang oleh penjajah Belanda namun justru di tempat itu Sukarno mendapatkan inspirasi untuk mulai merumuskan falsafah bangsa Indonesia yang nantinya disebut Pancasila. Selain itu, Ende merupakan tempat di mana terdapat pemukiman Muslim di tengah penduduk Flores yang mayoritas Katholik. Keinginan untuk mengetahui seluk beluk Ende menjadi motivasi perjalananku ke Ende. 


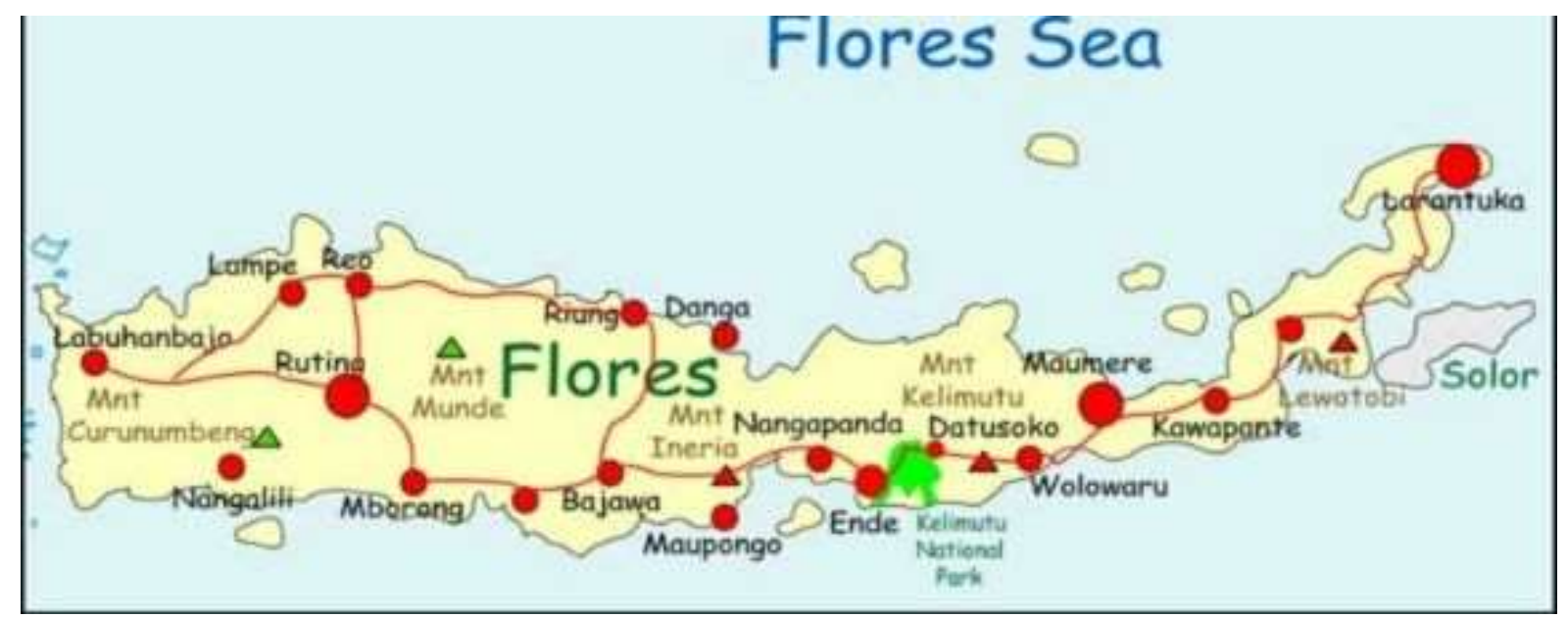

Gambar 1. Ende di Tengah Pulau Flores

Pulau Flores, namanya diambil dari nama sebuah tanjung yang berada di sebelah timur Pulau Flores, yaitu Tanjung Bunga atau Capo da flores dalam bahasa Portugis. Namun akhirnya nama itu dilembagakan menjadi nama keseluruhan pulau itu. ${ }^{1}$ Pulau Flores mempunyai luas daratan 14.273 Km2, di sebelah selatan Laut Sawu dan di sebelah Utara Laut Flores. Pulau Flores dari atas pesawat nampak permukaannya seperti kue kukus yang merekah berwarna kehijauan rerumputan sabana. Pemukiman masih terasa jarang, terkonsentasi di beberapa titik dari pulau itu. Pulau Flores sendiri memanjang dari Manggarai di sebelah Barat dan Larantuka di sebelah Timur. Dari arah barat bisa disebutkan beberapa kabupaten di Flores, yaitu: Manggarai, Ngada, Ende, Maumere, Larantuka (Flores Timur). Pulau Flores belakangan menjadi perhatian dunia sejak Pulau Komodo di Manggarai Barat dijadikan sebagai daerah tujuan wisata dunia karena keunikan makhluk raksasa bernama Komodo.

Penduduk Ende dari sisi jumlah pemeluk agama antara Katholik dan Islam hampir fifty-fifty. Memang secara statistik jumlah Katholik lebih banyak sedikit dibandingkan dengan Muslim. Menurut

\footnotetext{
${ }^{1}$ I Ketut Wardana yang mengutip P. J. Veth (Het Eiland Flores) dalam buku "Penataan Nusa Tenggara Pada Masa Kolonial 1915-195o:, Jakarta: Raja Grafindo, 2005ng luas di Terong. Namun karena H Mahmud Eka .
}

data BPS 2010 disebutkan jumlah penduduk Ende berjumlah 268.658 orang. Dari jumlah itu 70,06\% beragama Katholik, 26,46 \% beragama Islam, 3,04 \% beragama protestan, $1 \%$ beragama Hindu, Buddha dan Konghucu.

Dibandingkan daerah lain, Ende merupakan salah satu kantong muslim di Pulau Flores, selain di Manggarai. Sementara itu Pusat Keuskupan Agung untuk wilayah Nusa Tenggara juga berada di Ende, maka daerah Ende ini menjadi istimewa untuk menjadi obyek kajian mengenai mengenai perkembangan agama di Flores. Kajian ini nantinya diharapkan dapat menemukan satu konstruksi kerajaan Islam di daerah Nusa Tenggara Timur.

Masyarakat Ende berhasil menciptakan kerukunan umat beragama sedemikian rupa. Jarang terdengar konflik keagamaan terjadi di daerah ini. Konflik yang ada lebih cenderung terjadi pada persaingan antar marga atau Fam yang ada. Masing-masing marga/fam ingin diakui eksistensinya. Untuk itu masingmasing fam saling berkompetisi untuk mendapatkan pengakuan dari pihak lain. Hal ini terjadi pada masing-masing kelompok keagamaan. Hal ini pula yang menyebabkan orang lokal tidak mudah menerima gagasan atau kepemimpinan dari orang di luar mereka. Masalah relasi sosial ini dalam pengamat penulis menjadi masalah utama dalam memajukan masyarakat Ende. 
Sejarah kerukunan di Ende, pengkaji menduga hal itu disebabkan proses yang panjang dari keberadaan dua agama utama di kota ini, yaitu Islam dan Katholik. Islam hadir di kota ini pernah melembaga menjadi kerajaan Islam Ende, dan Katholik pernah hadir sejak 1556 di Pulau Ende dan pada tahun 1913 pusat keuskupan di Roma menjadikan Ende sebagai pusat keuskupan di seluruh wilayah Nusa Tenggara Timur. Kehadiran dua agama ini mau tidak mau tidak mau telah berdialog panjang dan menuntut kerukunan hidup bersama untuk hidup berdampingan.

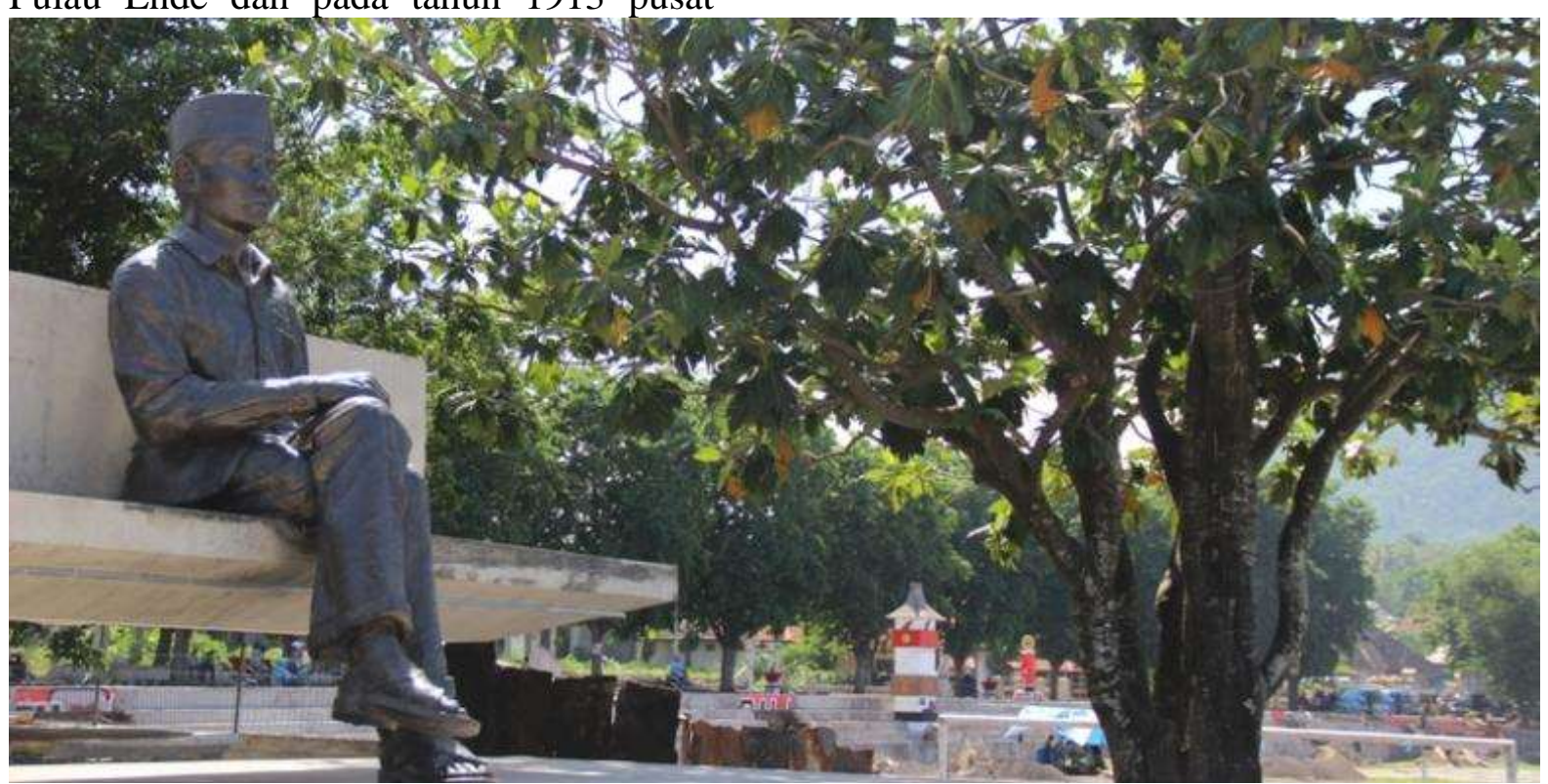

Gambar 2. Patung Soekarno dalam Pembuangan di Ende 1934-1938

\section{Dinamika Sejarah Islam di Ende}

Nurcholis Madjid pada tahun 1990an dalam sebuah seminar di Hotel Ambarukmo, Yogyakarta yang dihadiri penulis pernah menyatakan bahwa pendudukan Malaka oleh Portugis pada tahun 1511 telah menjadi pendorong perkembangan Islam yang luar biasa ke seluruh antero nusantara. Para pelarian muslim dari Malaka yang bersambung dengan aktifitas para pedagang telah menyebarkan dan mengkonsolidasikan kekuatan islam ke berbagai daerah pantai seperti Aceh, Banten, Cirebon, Demak, Goa, Ternate, Tidore dan daerah-daerah pantai lainnnya, termasuk bandar-bandar laut di nusa tenggara timur (NTT). Sebagian dari daerah-daaerah itu pada saatnya melakukan perang terhadap kekuatan kolonial Portugis ini.

Kedatangan orang Portugis yang nantinya membawa Katholik di wilayah Nusa Tenggara timur yang pertama kali tercatat Pada tahun 1561, ditandai dengan kehadiran kedatangan 3 orang, yaitu P. Antonio da Cruz, P. Das chagas dan Bruder Alexio ke Lohayong, Solor Flores Timur yang datang dari Malaka. Ini data yang sering disebut sebagai dasar penyebutan Katholik datang lebih dahulu di NTT dibandingkan Islam. Sejak itu kemudian Lohayong kemudian dijadikan oleh Portugis sebagai pangkalan dengan dibangunnya benteng Portugis (1566) dan menjadi awal penyebaran Katholik di Nusa Tenggara Timur (NTT). Dari Lohayong ini misi Katholik menyebar ke pantai-pantai sekitar seperti Larantuka, Ende, adonara, Lamakera bahkan ke daratan Timor. Khusus di Ende, Portugis dengan alasan ingin menghadapi prompak muslim dari Jawa, maka didirikanlah benteng Portugis yang kedua di NTT setelah Lohayong yaitu di Ende pada tahun 1596.

Sementara menurut versi Islam, masyarakat Islam khususnya yang tinggal di Menanga Pulau Solor Flores Timur merasa datangnya Islam lebih dulu 
dibandingkan kedatangan Portugis di Lohayong. Buktinya Islam di daerah ini telah berhasil membangun identitas politik lokal untuk melakukan perlawanan dengan Portugis. Kalau pemeluk Islam belum ada di situ, mana mungkin islam dan penduduk lokal dalam waktu singkat mampu melakukan gerakan perlawanan terhadap Portugis. Bukti lain kehadiran Islam di daerah itu yang diajukan oleh Penduduk Muslim Solor adalah jauh sebelum Portugis datang, telah ada penyiar agama islam di Solor, tepatnya di desa Menanga dengan ditandai makam Jou Pattiduri (abad $13 \mathrm{M}$ ) dan adanya keturunannya di daerah itu.

$$
\text { Pada tahun 1613, dibawah }
$$

kepemimpinan sultan Menanga, bekerja sama dengan kekuatan VOC yang mencoba menggeser Portugis dan menanamkan pengaruhnya di daerah ini, kekuatan islam melakukan perlawanan terhadap Portugis dan berhasil merebut benteng Lohayong. Sejak penakhlukkan itu, kekuatan Islam melembaga dalam bentuk kekuatan persekutuan kerajaankerajaan Islam kecil di sekitar itu. Ini berarti sebelum tahun itu, di sana telah terdapat lembaga-lembaga kerajaan Islam lokal yang lebih kecil.

Catatan lain menunjukkan Islam telah hadir di NTT, menurut berita Pigaffeta, salah seorang anggota rombongan Magelhaens dalam perjalanan mengelilingi dunia, yang sempat singgah di pelabuhan Batugede di pantai utara pulau Timor pada tanggal 22 Januari - 10 Pebruari 1522, di Alor waktu itu telah terdapat sebuah kampung Islam yang bernama Kampung Maluku (Yamin, 1962).

Sejarahwan Islam di Kupang, Munandjar Widiatmika, menyebutkan angka tahun kehadiran Islam di Ende pada tahun 1550. Sementara itu Katholik Diinformasikan pada tahun 1556 bahwa Pater Taveiro (Portugis) telah memandikan 5000 jamaah yang terdiri dari orang Pulau Ende dan Pulau Timor. Misi Katholik melembaga pertama kali di NTT dimulai dengan keberadaan Benteng Lohayong pada tahun 1561 tidak menutup kemungkinan pada tahun-tahun setelah itu selanjutnya juga hadir di Ende. Portugis kemudian juga membangung Benteng di Pulau Ende pada tahun 1596. Tujuan pembangunan Benteng itu adalah untuk menjaga kepentingan Portugis di Pulau Ende dari pengaruh Muslim dari Jawa. ${ }^{2}$

Terkait dengan kerajaan Islam Ende, diinformasikan bahwa pada tahun 1620 - 1630, Benteng Portugis di Ende diserang habis oleh orang Ende Daratan, khususnya Orang barrai. Kejadian dipicu oleh kejadian seorang gadis Barrai bernama Putri Rendo yang ditaksir oleh panglima Benteng, namun dalam waktu yang sama gadis itu juga disukai oleh seorang imam Katholik. Karena berebut ini si imam membunuh panglima benteng, dan si gadis Barrai melarikan diri ke Ende Daratan dan meninggal dunia di sana. Tidak terima gadis Barrai terusir dan mati, maka orang Barrai menyerang Ende dan membunuh semua orang Portugis di sana. ${ }^{3}$

Kejadian itu barangkali hanya faktor kebetulan di mana kekuatan Ende daratan yang dimotivasi oleh kekuatan yang disinyalir kekuatan Islam yang menolak penjajahan sudah lama mengincar ingin menyerang Benteng Portugis di Pulau Ende. Peristiwa Kejadian ini menjadi penjelas kenapa sejak itu, Pulau Ende tidak lagi menjadi pusat kekuatan Portugis dan misinya, karena sejak itu masyarakat pulau Ende seluruhnya masuk Islam. Pada tahun 1631, setahun setelah penyerangan, sebuah Masjid di pulau Ende dirikan oleh $\mathrm{H}$ Zainudin dan masjid ini dipercaya sebagai masjid pertama di Ende.

Informasi di atas juga menunjukkan bahwa ketika jauh sebelum penyerangan Portugis di Pulau Ende, telah terjadi penguatan Islam di Ende Daratan.

\footnotetext{
2 Munandjar Widyatmika, Sejarah Islam di Nusa Tenggara Timur (Kupang: Pusat Pengembangan Madrasah, 2002), h. 43

${ }^{3}$ Munandjar Widiatmika, Lintasan Sejarah Bumi Cendana (Kupang: Pusat Pengembangan Madrasah, 2002), h. 363.
} 
Secara bersamaan habisnya orang portugis di Pulau Ende, menjadi awal kajian tentang ende beralih ke Ende Daratan. ${ }^{4}$ Saat-saat itu diperkirakan munculnya kerajaan Islam Ende yang berpusat di Ambu Tonda, Kecamatan Kotaraja, Ende.

Hadirnya kerajaan Ende menandai perkembangan Islam di Ende. Dari berdirinya kerajaan Ende dengan Jari Jawa sebagai raja pertamanya, nampaknya Islam mengalami berkembangan tanpa ada saingan yang berarti dari Portugis. Pengaruh Portugis untuk sementara tertahan di Flores bagian Timur yaitu Larantuka dan Sikka. Sementara Flores bagian Barat sudah dimasuki pengaruh Islam seperti Manggarai dan Ende. Sementara daerah Ngada masih didominasi kepercayaan animistik.

Perkembangan Islam di daratan Flores punya warna agak khas yaitu lebih banyak diwarnai formasi politik di mana daerah-daerah flores menjadi daerah kekuasaan dari penguasa Islam Sumbawa atau Islam Goa Makassar. Fakta alam yang berbukit-bukit dan penduduk yang jumlahnya sedikit dan hanya tinggal di titik-titik tertentu dan tingkat komunikasi antar titik yang rendah menjadi gambaran kenapa agama Islam tidak berkembang pesat di Flores. Tradisi keilmuan yang menjadi warna utama perkembangan Islam kurang berkembang di kalangan Muslim Flores ini. hal ini mengakibatkan pemahaman Islam di Flores tidak sekaya atau sedalam seperti di Jawa, Sumatera, Kalimantan dan Makassar. Fenomena yang agak sama terjadi di Maluku Kepulauan. Gairah tinggi untuk belajar Islam secara keilmuan tidak terlalu nampak dari daerah ini.

Namun perkembangan Islam di Ende dari tahun 1630, yaitu terusirnya Portugis dari Pulau Ende hingga 1850 di mana penguasaan wilayah Flores diserahkan kepada Belanda, dengan segala

\footnotetext{
4 Pater Piet Petu. "Sekitar Noa Roja-Nua Ende" (Ende: Sekretariat Panitia Pengumpulan Data Sejarah Berdirinya Kota Ende, tt), h. 17
}

keterbatasannya, eksistensi kerajaan Islam Ende tidak begitu terganggu. Memang tidak banyak bukti yang bisa dihadirkan sebagai kemajuan Islam di Ende ini, karena memang Islam di Ende belum menjadi bahasa Ilmu, tapi paling tidak kekuasaan kerajaan Ende cukup otonom pada saat itu. Hubungan kerajaan Ende dengan kolonial dalam hal ini belanda sejak Portugis terusir dari Lohayong (1613) dan Pulau Ende (1630) pun awalnya terbangun dalam bentuk kontrak kerjasama (1793), antara dua lembaga yang seimbang. Walaupun dalam perkembangannya, di masa Belanda ini, raja Ende terkesan ambigu, mencari selamat dan kurang berpihak kepada rakyat. Namun di sisi lain, kehadiran Islam tidak terganggu oleh kehadiran misi agama lain di Ende.

Menurut Ardhana, mengutip Nunheim, kekuasaan Portugis di Flores sejak jatuhnya Benteng Lohayong di Solor (1613) tidak berkembang. ${ }^{5}$ Demikian juga di Ende, Portugis setelah juga terusir dari Pulau Ende di mana Benteng dan orangorang Portugis di habisi oleh orang Ende daratan pada tahun 1630. Sejak itu perkembangan misi Katholik tidak terbina dengan baik. Ini memberi kesempatan Islam hadir dan melembaga dalam bentuk kerajaan Islam Ende dan cukup eksis untuk beberapa periode. Terusir dari Lohayong, Portugis tidak bisa menguasai sepenuhnya Flores kecuali di Flores bagian Timur, yaitu Larantuka dan Sikka.

Gambaran secara umum di Ende antara 1859-1907 banyak diwarnai sikap protes masyarakat terhadap kerajaan Ende yang tunduk kepada Belanda. Beberapa peperangan dari rakyat yang ditujukan kepada Belanda seperti pemberontakan Bharanuri, Mari Longa. Belanda mulai intervensi secara kuat dan mengambil alih kendali kekuasaan sepenuhnya setelah munculnya kesadaran perlawanan rakyat terhadap eksistensi Belanda. Perlawanan

\footnotetext{
5 Ardhana, I Ketut, Penataan Nusa Tenggara Pada Masa Kolonial 1915-1950. (Jakarta: PT RajaGrafinda Persada, 2005).
} 
rakyat itu dipimpin diantaranya oleh tokoh Muslim yang berseberangan dengan Raja Ende, yaitu Bharanuri yang melawan Belanda pada tahun 1887-1891.

Sementara itu, perkembangan Katholik di Ende baru setelah tahun 1850an, setelah klaim kekuasaan Portugis atas bumi Flores diserahkan ke Belanda tepatnya $1859,{ }^{6}$ Misi Katholik mendapatkan momentum yang pas dengan datangnya masa politik etis dari Belanda. Sejak itu data yang ada menunjukkan perkembangan agama Katholik yang signifikan. Padahal pada tahun 1907 menurut FX Sunaryo yang mengutip Pater Looijmans yaitu Pastor Stasi Lela sebelum tahun itu di Ende belum ada orang Katholik. ${ }^{7}$ Pengembangan misi Katholik baru dimulai ketika Mgr Noyen singgah di Ende atas permintaan Nyonya Hens, istri Controleur Hens (petugas Belanda) yang karena melihat kondisi Ende yang damai kemudian menyetujui misi Katholik dapat mulai dikembangkan di Ende. Pada tanggal 28 April 1911 Pater Looijmans mengunjungi Ende melihat peluang pengembangan Katholik. Pada tahun 1912 Pater Looijmans kembali ke Ende untuk menerimakan sakramen-sakramen dan mempermandikan anak-anak. Tahun berikutnya, 1913 Ende dijadikan pusat misi Katholik di Pulau Flores.

Sejarah lebih awal menyebutkan, Pada tahun 1862, pengembangan Katholik di Flores dijajaki oleh Ordo Jesuit. Pada tahun 1875, satu Ordo yang nantinya menggantikan Ordo Jesuit, yaitu Ordo Serikat Sabda Tuhan atau yang terkenal SVD (Societas Verbi Divini), yang didirikan Fr Arnold Janssen di Steyl Belanda, juga pernah mengunjungi Flores. ${ }^{8}$ SVD inilah yang nantinya berhasil mengKatholikkan hampir seluruh Pulau Flores. Secara umum sebelum 1907, misi

\footnotetext{
${ }^{6}$ Ardhana, I Ketut, Penataan Nusa ...h. 53-57.

7 FX Soenaryo dkk., Sejarah Kota Ende (Ende: Dinas Pendidikan dan Kebudayaan, 2006), h. 135.

${ }^{8}$ Ardhana, I Ketut, h. 74-75.
}

Katholik yang didukung Belanda belum menggarap Ende secara maksimal.

Periode 1913-1943, gerakan gereja di Flores berkembangan secara masif hingga pada tahun 1943 jumlah Umat Katholik di Flores sudah mencapai separuh lebih. Kesaksian Kapten Tasuku Sato, seorang kapten Jepang yang dikirim ke Flores 1943, memberi kesaksian perkembangan Katholik di Flores yang luar biasa hanya dalam waktu 30 tahun (1913-1943) berhasil menasbihkan 400.000 orang masuk agama Katholik. ${ }^{9}$ Demikian perkembangan Katholik relatif dominan hingga kini.

Naiknya jumlah umat Katholik lebih banyak disebabkan adanya perpindahan agama penduduk dari keyakinan animisme ke Katholik. Peran gigih para pastor di lingkungan gereja mampu meyakinkan penganut animistik itu untuk lebih memilih Katholik daripada Islam. Hingga puncaknya Katholik menjadi agama mayoritas di pulau Flores. Pembangunan umat katholik di Ende dan Flores melalui pendidikan, penerbitan buku seperti Nusa Indah di Ende patut menjadi cermin dalam memajukan umat beragama. Banyaknya orang pintar dari Flores adalah produk dari pendidikan yang diselenggarakan Sekolah Katholik.

Sementara itu, perkembangan Islam di Ende ini relatif stagnan. Dari pengamatan penulis ada beberapa penyebab tidak berkembangnya Islam di bumi Flores. Pertama, Sejak Belanda mengembangkan politik etis, dan Belanda mulai mengenalkan Pendidikan bekerjasama dengan pihak gereja, menyebabkan misi zending bisa mendekati seluruh pelosok Flores sehingga penduduk lokal yang masih penganut animisme di Pulau Flores cenderung banyak memeluk Katholik daripada Islam yang dakwahnya kurang agresif. Kedua, peran ambigu kerajaan Islam Ende pada zaman kolonial

\footnotetext{
9 Tasuku Sato dan P Mark Tennien, Aku Terkenang Flores, (Ende: Penerbit Nusa Indah, 2005). h. 4344.
} 
yang seakan-akan mengambil posisi di ketiak Belanda karena beranggapan Belanda lah yang membantu mengusir Portugis dari Flores. Hal itu membuat Islam kurang menarik simpati masyarakat Ende, bahkan memicu perlawanan terhadap eksistensi kerajaan dari rakyatnya. Ketiga, fakta alam flores yang berbukit-bukit dan minimnya sumber daya alam yang bisa dieksplorasi serta realitas sosial Ende yang masih dominan berbangga-bangga dengan pengelompokkan marga atau fam telah membuat kedirian masyarakat Islam terbelah. Ini berbeda dengan umat Katholik yang terpusat tidak saja dalam lingkup keuskupan lokal tetapi juga dalam jaringan internasional membuat kebanggaan terhadap fam dan marga di lingkungan Katholik dapat dikomunikasikan sedemikian rupa sehingga terhindar dari segala hal yang bersifat kontraporduktif. Keempat, khazanah Islam belum berkembang dalam bahasa keilmuan. Agama masih sebatas penyampaian dakwah yang direalisasikan dalam kegiatan yang lebih cenderung ritualistik. Tradisi keagamaan yang belum diterjemahkan dalam bahasa ilmu Ini mengakibatkan kemiskinan pada daratan kontruksi dan reproduksi keilmuan yang bersumber dari ajaran Islam di Ende.

Belakangan setelah reformasi 1998, nampaknya ada sedikit perkembangan menarik dari jumlah umat Islam di Ende. Keterbukaan informasi, demokrasi telah membuka ruang dialog yang lebih luas pada masyarakat yang menyebabkan ada keterbukaan akses dalam bidang pembangunan sosial. Dalam demografi keagamaan, ada perkembangan menarik dari jumlah umat Islam berdasarkan data BPS tahun 2002 dan 2003. Pada tahun 2002 disebutkan jumlah Umat Islam di Ende 28.524. jumlah itu ternyata pada tahun 2003 berkembang menjadi 32.661. sementara umat Katholik mengalami penurunan dari 35.807 (tahun 2002) menjadi 34.595 (tahun 2003). Kemungkinan terbesar naiknya jumlah populasi umat Islam disebabkan bertambahnya para pendatang di bumi Ende dari luar daerah seperti Jawa, Makassar, Padang karena ingin berdagang di Ende. Sisi yang lain adalah aktifnya gerakan dakwah ke desa-desa melalui silaturahmi dari masjid ke masjid yang memantabkan iman umat beragama yang selama ini kurang terbina, yaitu umat beragama yang masih ikut-ikutan.

Pasang surut demografi keagamaan dalam masyarakat modern adalah masalah pilihan yang bisa diambil dan diputuskan oleh siapa saja dan terkadang tidak terhindarkan. Daripada menajamkan perbedaan, tekad masyarakat Ende untuk mengedepankan kerukunan dalam hidup bermasyarakat adalah khazanah keagamaan Ende yang luar biasa. Keberadaan agama Katholik dan Islam yang saling bahu-membahu dalam memajukan masyarakat Ende menjadi model kerukunan yang bisa dirujuk dalam pengembangan kemitraan antar agama di daerah lain di Indonesia. Kerukunan yang rasional dan demokratis akan menjadi modal utama dalam meningkatkan penghayatan keagamaan.

\section{Mengenal Pesantren Walisanga}

Di tengah dinamika keagamaan dan kerukunan di Ende, terdapat sebuah lembaga pendidikan keagamaan Islam yang sering ditunjuk sebagai model melestarikan kerukunan, yaitu pesantren walisanga di Ende. Misalnya salah satu kegiatan ko-korikuler SMPN 2 Ende, sekolah dengan jumlah siswa mayoritas beragama Katolik, adalah berkunjung ke pesantren tertua di Nusa Tenggara Timur, yaitu Pesantren Walisanga. Kegiatan ini tidak hanya dilakukan oleh siswa Muslim, tetapi juga semua siswa baik muslim, katholik dan kristen. Tujuannya adalah membangun pengetahuan bersama khazanah keagamaan yang ada di Ende sekaligus mengenal sosok pendiri pesantren, $\mathrm{H}$ Mahmud Eka yang berwawasan multikultural. 


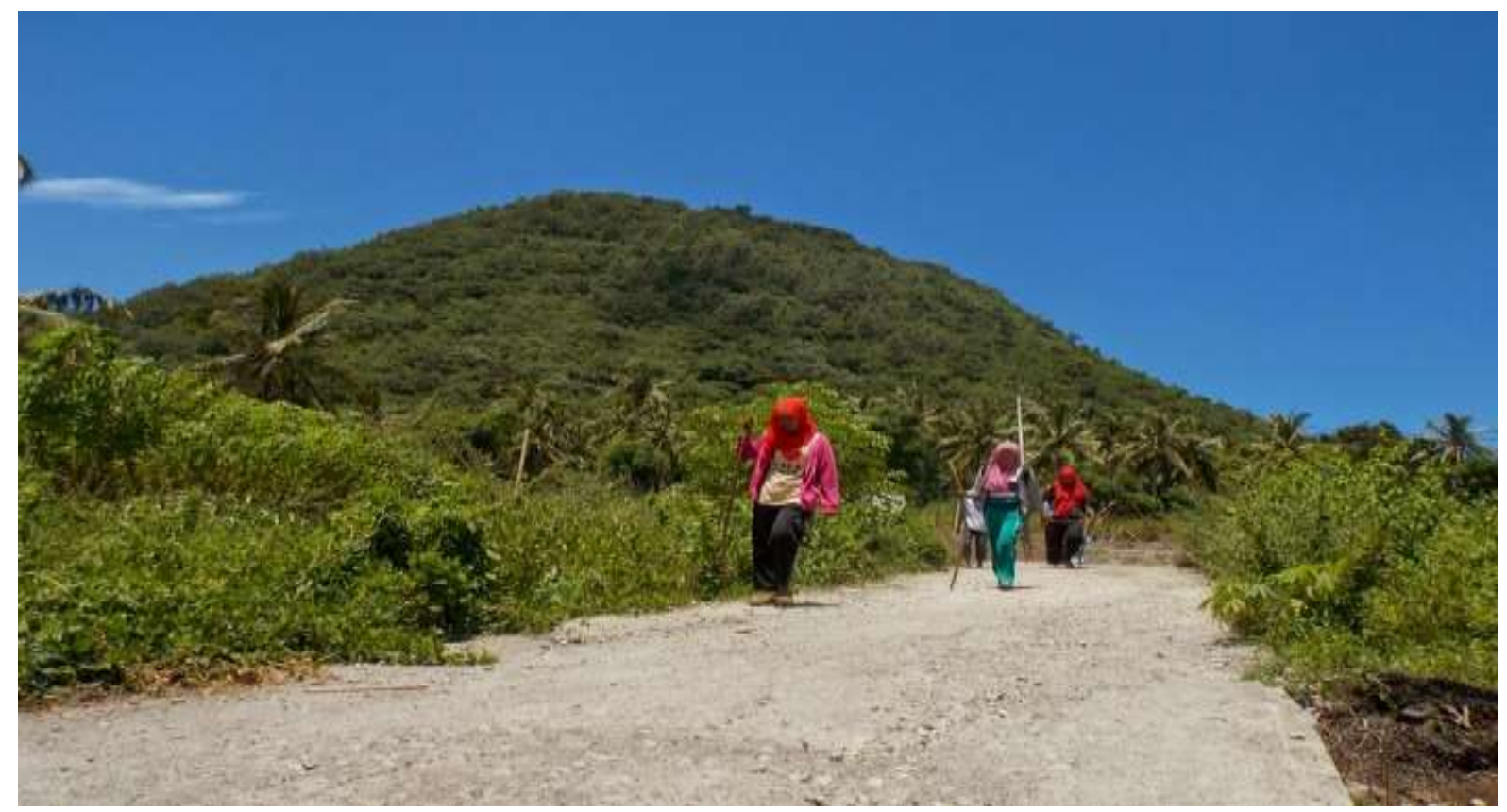

Gambar 2. Suasana Jalan Sekitar Pesantren Walisanga

Untuk mencapai pesantren walisanga, kita harus menyusuri jalan ke arah Gunung Meja di Ende, sebuah gunung yang di atas terdapat permukaan yang rata seluas lapangan sepak bola, tepatnya di lereng Gunung itu posisi pesantren Walisanga berada. Di situ terdapat komplek pendidikan yang merupakan lembaga yang dimiliki pesantren Walisanga. Pesantren walisanga adalah pesantren pertama yang didirikan oleh H. Mahmud Eka. Pesantren walisanga menempati lokasi itu yang sebenarnya lokasi baru dimulai pada tahun 2003. Sebelumnya Pesantren Walisanga menempati tanah di Jalan Perwira.

Pesantren Walisanga berdiri pada tahun 1981. Saat pertama pesantren berdiri, Sang pendiri yaitu H Mahmud Eka mengagas pesantren awalnya justru terinspirasi dan didorong oleh seorang Pastur Belanda bernama Pater Baack. Saat itu Pastur Pater Baack menyarankan Mahmud Eka untuk mendirikan Panti Asuhan untuk anak-anak Muslim. Pastur itu menyatakan bahwa di panti asuhan yang dimiliki umat Katholik di Ende, yaitu Panti Asuhan Naungan Kasih, terdapat beberapa anak muslim yang perlu mendapat perhatian. Pastur itu mendorong Mahmud Eka untuk menggagas Panti
Asuhan di kalangan Islam. Atas dorongan itu kemudian Mahmud Eka terpanggil untuk mulai memperhatikan anak-anak muslim melalui Panti Asuhan.

Merenungkan bahwa terdapat kebutuhan yang besar di kalangan Islam harus ada panti asuhan, maka $\mathrm{H}$ Mahmud Eka di jalan Perwira membangun panti asuhan. Alih-alih mengelola anak di pondokan, $\mathrm{H}$ Mahmud Eka menganggap penting sekaligus menggagas pesantren. Maka jadilah panti asuhan itu diberi anma pesantren walisanga. Pesantren ini agak mengususkan diri menerima anak-anak yatim dan anak tidak mampu. Para santrinya sekarang ini berasal dari ujung barat pulau Flores, Manggarai hingga flores timur, yaitu pulau Lembata.

Untuk melayani pendidikan formal bagi anak-anak yatim, maka pesantren Walisangan menyiapkan beberapa jenjang pendidikan yaitu MTs dan MA bagi para santri dan masyarakat sekitar.

Berjarak kurang lebih $4 \mathrm{Km}$ dari Bandara $\mathrm{H}$ Aburusman Ende, Pesantren walisanga berada di lereng Gunung Meja. Untuk menuju ke sana, kita bisa mengendarai mobil sewaan yang banyak tersedia di Bandara dengan ongkos kurang lebih 100 Ribu. Bertempat di sela-sela lereng pegunungan menyebabkan lokasi 
pesantren ini terasa berada di luar kota. Melewati jalan yang sepi di lereng penunungan menimbulkan rasa penasaran tersendiri untuk mengetahui pesantren tertua di nusa Tenggara Timur (NTT) ini.

Setibanya di lokasi, kami dihadapkan beberapa pembangunan gedung yang belum selesai dan gambaran beberapa anak santri yang sopan menyalami kami. Bangunan rumah susun bantuan pemerintah yang hingga saat penulisan ini dilakukan belum diserahkan ke pesantren. Pesantren walisanga berada di Jalan Ikan Duyung, Kelurahan Rukun Lima, Ende Flores.

H. Mahmud Eka mempunyai nama lengkap $\mathrm{H}$ Mahmud Ebong Kanehang. Ebong Kanehang disingkat menjadi "Eka". Sehingga ia dikenal sebagai $\mathrm{H}$ Mahmud Eka. Ia lahir 23 September 1939 di wilayah Lamakera, Solor, Flores Timur. Lahir dari pasangan Abong dengan Siti Aminah. Menurut pengakuan anaknya, Halimah, konon ayahnya itu sebenarnya mempunyai keluarga dan tanah warisan yang luas di tanah kelahiran, namun karena $\mathrm{H}$ Mahmud Eka tidak pernah mengajarkan anaknya untuk mengungkitungkit haknya di tanah kelahiran, sehingga sampai kini Keluarga H Mahmud Eka tidak lagi menyinggu-nyinggung kekayaan yang dimiliki di tanah kelahiran.

Mahmud Eka dilahirkan dengan kecerdasan dan sifat rendah hati. Karena kecerdasannya, Eka kecil ketika menempuh pendidikan setingkat Sekolah Menengah Pertama (SMP) sudah terlibat mengajar untuk adik-adik kelasnya. Karena kecerdasanya pula, Mahmud Eka muda di ajak keluar dari desanya untuk meneruskan pendidikan di Ende.Mahmud Eka meneruskan pendidikan di Pendidikan Guru Agama (PGA) Ende. Setamat dari PGA, Mahmud Eka meneruskan pendidikan di Perguruan Tinggi Pemerintahan dan Masyarakat (PTPM). Mahmud Eka selain cerdas mempunyai sifat kerendahan hati, hal ini akan nampak mewarnai perjalanan hidupnya.

\section{H Mahmud Eka: Pendiri Pesantren Walisanga}

H Mahmud Eka dikenal sebagai perintis pesantren pertama di sNusa Tenggara Timur (NTT) yang membangun pesantren di Kabupaten Ende. Selama hidupnya diabdikan untuk pengembangan dan pembinaan agama Islam di Ende. Pesantren yang digagas oleh $\mathrm{H}$ Mahmud Eka adalah pesantren yang lebih banyak memfokuskan pada pembinaan anak-anak yatim/piatu. Peantren mempunyai anak didik yang membentang dari ujung barat Pulau Flores, Manggarai dan ujung Timur Plau Flores, Larantuka. Bahkan sampai Pulau Lembata.

Di Ende, Madmud Eka terpanggil untu turut mengembangkan agama Islam di Ende. Karena kecerdasan dan kerendah hatiaanya ia mempunyai pergaulan yang luas di Ende. Dia mempunyai kedekatan dengan para pastur di Ende. Dari para pastur ini, Madmud Eka mengenal budaya disiplin dan pentingnya pengembangan pengetahuan dalam hidup manusia.

Justru karena pergaulan denga Pastur ini, akhirnya Mahmud Eka berteman dekat dengan seorang Pastur asal Belanda yang bernama Pater Baack. Pastur inilah yang mengenalkan Mahmud eka pentingnya sikap kepedulian sosial dan aksi kemanusiaan. Mahmud Eka ditunjukkan dengan kehidupan Panti Asuhan. Dari sini, Pater Baack membisiki sekaligus mendorong Mahmud Eka untuk mendirikan panti asuhan untuk anak-anak Islam di Ende. Mahmud Eka ditunjukkan bahwa di panti asuhan Naungan Kasih ada terdapat anak-anak muslim yang dibina di panti asuhan tersebut.

Terdorong oleh dorongan Pater Baack dan melihat realitas masyarakat yang membutuhkan pertolongan baik itu karena anak yatim atau kemiskinan, pada tahun 1981 Mahmud Eka mendirikan pesantren.

Beberapa usaha mengembangkan pendidikan agama di Ende, telah dilakukan oleh Mahmud Eka. Pada Usia 72, akhirnya sang perintis pesantren di Pulau Ende 
dipanggil keharibaan ilahi. Mahmud Eka Meninggal 19 Mei 2011 di tengah-tengah santri yang mengelilinginya. Kematiannya seperti itulah yang diimpikan oleh Mahmud Eka, dia bisa dicabut nyawanya oleh Malaikat Izroil di tengah-tengah anak-anak yatim yang dibinanya. Kematiannya sepertinya sudah dipersiapkan betul oleh Mahmud Eka. Sehari sebelum azalnya, Mahmud Eka menuruh semua santrinya untuk kerja bakti membersihkan lingkungan pesantren. Mahmud Eka menyatakan bahwa besok akan banyak tamu datang, maka semua lingkungan harus kelihatan bersih.

\section{Melawan Kerasnya Tantangan Alam}

kenyataan alam Pulau Flores yang bergunung-gunung dan irigasi yang kurang mencukupi di Pulau Flores menjadi tatangan tersendiri bagi daerah Ende untuk menjadi sebuah pemukiman atau kota yang memadai untuk semua keperluan, termasuk pengembangan pendidikan pesantren. Ende berkembang menjadi kota kecil dengan tingkat perputaran modal yang terbatas. Dengan kondisi alam yang berbukit menyebabkan daerah Ende kurang kondusif menjadi daerah pertanian. Akibatnya masyarakat flores kebanyakan berada dalam posisi miskin.

Kondisi alam dengan kesulitan tersendiri ini menjadi warna tersendiri bagi pesantren walisanga. hingga saat ini pesantren ini masih mengalami kesulitan tersendiri dalam menakhlukkan alam ini, khususnya dalam penyediaan air bersih. Lokasi yang ada di lereng Gunung menyebabkan pesantren walisanga masih mengalami kesulitan dalam mendapatkan air bersih. Sekalipun hidup di Lereng Gunung, bukan berarti kesediaan air dari bukit gunung melimpah. Gunung-gunung di Flores bukan jenis gunung sebagai di Jawa yang menjadi hutan sehingga menjadi produsen air gunung yang melimpah. Gunung di Flores berbentuk karst sehingga hanya ilalang dan rerumputan yang tumbuh di atas tanah, sehingga gunung-gunung tersebut tidak menghasilkan cukup air.

Untuk memenuhi kebutuhan seharihari tentang air para santri harus menimba air. Di musim kemarau ketika air tidak ada, terpaksa pesantren membeli air dengan menggunakan truk tangki. Padahal harga air satu tangki tidaklah murah, dibutuhkan uang sebanyak Rp. 500.000,untuk satu truk tangki. Maka apa boleh buat, untuk memenuhi kebutuhan pesantren ini terpaksa membeli air melalui truk tangki. Pembelian ini bukan tanpa implikasi, karena pesantren harus menghemat air, maka para santri dan siapapun yang datang di lokasi itu diharuskan untuk hemat air. Akibatnya pelaksanaan toharoh di pesantren walisanga dipenuhi dengan segala keterbatasan.

Keterbatasan sumber daya alam yang terjadi di pesantren walisanga hanya merupakan gambaran tersendiri bagaimana susahnya tantangan keadaan alam Ende. Bentuk perjuangan tersendiri bagi orangorang pulau Flores untuk menakhlukkannya. Kota-kota antara kabupaten di tanah flores dihubungkan dengan jalan berkelok yang mengelilingi perbukitan. Dari pesawat udara, nampak tekstur tanah pulau flores yang berombak. Pemukiman satu dengan pemukiman lain nampak berjarak berjauhan. Nampak sekali komunikasi sesama warga dari pemukiman satu ke pemukiman lain masih terbatas. Dengan kondisi seperti itu maka primordialisme kelompok menjadi nyata adanya karena terbatasnya komunikasi.

\section{Menghadapi Primordialisme Kelompok}

Permasalahan berikutnya yang dihadapi perkembangan Islam di Ende, menurut pengkaji adalah masih besarnya fanatisme kelompok sosial. Entah karena kerasnya alam atau oleh latar belakang sebab yang lain terbatas menyebabkan manusia di Pulau Flores ini secara rata-rata umum digambarkan sebagai mereka dengan kecakapan rendah (Less-skills), 
watak keras, lambat berfikir. Walaupun di sisi lain ada kesan orang-orang ende nampak masih lugu, jujur dan tidak berani macam-macam. Menurut pengakuan Halimah, Pengasuh Pesantren Walisanga, kenyataan mendasar masyarakat Ende adalah ketertinggalan. Mereka anak-anak secara umum mempunya kelemahan yaitu agak lambat berpikir, hal ini yng menyebabkan anak-anak Flores cenderung rendah secara intelektual.

Keadaan itu diperburuk oleh realitas kultur di mana masyarakat di Ende masih lekat dengan sikap primordialisme masyarakat Ende terhadap kelompok fam atau marga masing-masing. Implikasi dari sikap primordialisme ini dirasakan oleh orang pendatang bahwa Orang Ende kurang mengapresiasi orang luar dari fam nya, termasuk para pendatang, sekalipun orang lain atau yang datang itu pintar. Akibatnya gagasan kemajuan kurang bisa diintrodusir oleh orang-orang yang ingin membangun Ende kurang terakomodasi secara cepat.

Semangat fanatisme terhadap marga atau fam di kebanyakan wilayah di Nusa tenggara Timur (NTT) ini hampir mirip dengan fanatisme terhadap fam atau marga di Maluku. Hanya saja kalau di Maluku fanatisme fam atau marga itu diperparah dengan pilhan terhadap agama tertentu. Hal ini menyebabkan konflik fam/marga di Maluku diperparah dengan konflik bernuansa keagamaan. Sedangkan bila masyarakat di NTT suasana agak berbeda karena orientasi keagamaan tidak terlalu mengikat fam/marga. Malahan orang NTT lebih mengutamakan hubungan darah sebagai dasar ikatan marga atau fam itu. Artinya pada masyarakat NTT kepentingan marga atau fam lebih dahulu ada dibandingkan dengan ikatan agama.

Hal itu dirasakan juga oleh pendiri pesantren Walisanga, Mahmud Eka, yang pernah menyatakan bahwa 40 tahun saya hidup di Ende saya masih dianggap orang asing oleh orang Ende. Akibatnya pengaruh Mahmud Eka, sekalipun dia mempunyai peran sejarah keagamaan yang besar di Ende, hanya diakui oleh sebagian kecil dari umat di Ende. Orang Ende masih memilih orang-orang dari kelompoknya sebagai orang yang dianggap tokoh.

Anggapan bahwa pesantren walisanga dirintis oleh muslim pendatang, sedikit banyak juga mempengaruhi animo masyarakat lokal untuk masuk menjadi santri di pesantren tersebut. Banyak santri di Pesantren Walisanga yang justru datang dari luar daerah Ende. Santri di pesantren itu lebih banyak menampung santri dari kabupaten lain seperti Manggarai, Ngada, Sikka, Adonara, Solor dan Lembata.

$$
\text { Latar belakang kuatnya }
$$

primordialisme ini pula yang menjadi alasan kenapa Mahmud Eka memilih dalam membina anak Yatim dan orang miskin dalam pesantren yang digagasnya memindahkan tempatnya lebih keluar dari kota Ende. Dengam membina anak-anak yang tidak berdaya, pesantren ini berharap tetap bisa membangun Ende dengan membina sebagian Sumber Daya Manusia (SDM) ende yang justru terpinggirkan.

Karena primordialisme juga, ada yang berkesimpulan bahwa Pesantren Walisanga terpaksa berpindah tempat ke Lereng Gunung Meja dari tempat awalnya di Jalan Perwira. Yayasan Tarbiyah yang banyak dikelola oleh orang Islam lokal akhirnya secara halus mengambil alih lokasi di Jalan Perwira dan dijadikan lembaga pendidikan Sekolah Menengah Kejuruan (SMK) Perikanan Ende. Malas untuk berkonflik, Mahmud Eka sang pendiri Pesantren Walisanga terima mengalah mencari lokasi baru. Dengan membangun lokasi baru, maka pengelolaan Pesantren Walisanga dapat dikelola lebih mandiri.

Mengahadapi primordialisme masyarakat Ende, walaupun agak kontradiktif karena pesantren Walisanga mempunyai karakter panti asuhan yang justru membutuhkan bantuan masyarakat lokal, pesantren walisanga dengan kemampuan komunikasi yang dimiliki pengelola dengan berbagai pihak di luar Flores, pesantren Walisanga berhasil 
mengundang bantuan dari pihak-pihak luar itu untuk memperbaiki image pesantren Walisanga. Maka lahirlah beberapa bangunan di kompleks pesantren seperti gedung MTs dan MA, pembangunan Rusunawa di lingkungan pesantren walisanga, pembangunan masjid.

Secara infrastruktur, fenomena pembangunan gedung-gedung di pesantren menyebabkan citra Pesantren Walisangan semakin naik. Dengan fasilitas yang lebih bagus, masyarakat lokal mulai melirik pesantren walisanga. Santri pesantren Walisanga banyak diundang untuk keperluan doa untuk orang yang meninggal atau mengajarkan pendidikan agama bagi anak-anak di masyarakat Ende.

Sebaliknya naiknya citra Pesantren Walisanga dengan kehadiran bangunanbangunan yang ada, dirasakan oleh pengurus pesantren bantuan dari masyarakat lokal menurun. Masyarakat menganggap Pesantren Walisanga sudah kaya dan tidak membutuhkan bantuan. Tentusaja pengurus pesantren merasa kelimpungan juga dengan kenyataan ini. Karena pada kenyataanya sumber pendanaan yang dimiliki pesantren ini masih sangat terbatas. Bangunan-bangunan dan properti yang hadir di pesantren ini hadir karena simpati pemberi bantuan dari luar daerah terhadap perjuangan dan misi mulia lembaga pendidikan ini.

\section{Marginalisasi dan Dominasi Keagamaan}

Sekalipun diakui bahwa tradisi pendidikan anak melalui panti asuhan yang berkembang di Katholik menjadi inspirasi bagi Mamud Eka, namun keberadaan dan kemajuan Katholik menjadi tantangan atau rival tersendiri bagi pengembangan pendidikan Islam di Ende. Sebagaimana di daerah manapun terdapat agama dominan, maka besar kemungkinan bahwa kelompok dominan akan mendapatkan keuntungan lebih dibandingkan dengan kelompok lain yang lebih kecil. Demikian juga dalam konteks masyarakat ende, di mana pemeluk agama Katholik di lingkup Kabupaten Ende merupakan kelompok terbesar, maka dalam politik lokal dan kebijakan pemerintah daerah diwarnai kecenderungan pembangunan yang menguntungkan pemeluk umat Katholik.

Kesan marginalisasi Islam di wilayah Ende nampak dalam eksplorasi budaya di Ende. Di Kab Ende di mana anda dua suku utama yaitu Ende dan Lio, dalam buku-buku yang terbit kesan suku Lio dikedepankan dari pada suku Ende. Suku Ende merepresentasikan Islam, sedang suku Lio merepresentasikan Katholik. Dalam buku-buku kepustakaan yang ada baik di perpustakaan daerah, toko-toko buku, buku-buku laporan pemerintahan nampak jelas sekali pemberitaan suku Lio lebih besar dari suku Ende. Padahal di Kota Ende keberadaan umat Islam hampir fifty-fifty.

Marginalisasi juga nampak dalam pemberitaan keberadaan sejarah kerajaan Islam Ende. Peradaban Ende yang awalnya merupakan sejarah awal perkembangan Islam di Ende, saat ini terbangun kesan bahwa kerajaan Ende seakan tidak ada. Bahan seakan ada pihak-pihak yang ingin secara sengaja menghapus sejarah kerajaan Islam ende. Bahkan terdengar kabar nama Bandara yang kebetulan nama raja Kerajaan Ende terakhir Hasan Aroeboesman ada suara-suara yang ingin menggantikan nama itu. Namun karena tanah bandara sebagian besar adalah pemberiaan Hasan Aroesboesman, maka penggantian nama itu hingga saat belum bisa dilakukan.

memang tidak menekan langsung keberadaan Pesantren Walisanga, karena pesantren ini lahir dan bentuknya banyak terinspirasi oleh peran sosial melalui panti asuhan yang justru dikembangkan dalam masyarakat Katolik. Kuatnya lembagalembaga pendidikan keagamaan Katolik di Ende, secara langsung dan tidak langsung menggeser kemampuan umat beragama Islam dalam mengembangkan pendidikan 
agama di daerah itu. Ketika sumber daya manusia muslim di daerah itu masih terbatas, peran misi Katholik hadir dengan sumber daya yang di dukung oleh modal misi internasional. Kekuatan inilah yang mnyebabkan Katolik lebih berhasil mengembangkan pendidikan agama di Pulau Flores.

\section{Bantuan Pendampingan dan Pengembangan SDM lebih dibutuhkan}

Susahnya medan perjuangan di Pulau Flores sedikit banyak telah menghadirkan simpati sebagian orang dari luar kota Ende terhadap perjuangan para pengasuh dan pengelola Pesantren walisanga Ende. Belakangan berbagai bantuan datang ke pesantren ini baik dari bantuan lembaga pemerintah yang berasal dari beberapa kementerian atau bantuan yang sifatnya pribadi. Beberapa bantuan yang datang itu antara lain pembangunan rumah susun di lingkungan pesantren, sumur pengeboran.

Dari berbagai bantuan yang hadir, melahirkan kesan bahwa pesantren Walisanga Ende tiba-tiba saat ini telah menjadi lembaga yang kaya. Kesan ini tidak selamanya menguntungkan, bahkan sebaliknya merugikan. Masyarakat berpandangan bahwa pesantren walisanga sudah kaya dan mapan dan tak perlu lagi dibantu karena sudah kaya. Kesan ini tentu saja merugikan bagi pengelola pesantren yang ingin membantu. Partisipasi masyarakat sekitar belakangan mulai menurun.

Melihat permasalahan ini, pembaca perlu mengkaji ulang. Barangkali bantuan yang lebih pas dalam pengembangan pendidikan keagamaan di wilayah Ende ini lebih membutuhkan model-model perbantuan seperti pendampingan dan pengembangan SDM lokal. Bantuan yang sifatnya semata-mata material tidak membantu secara subtantif untuk mengeleluarkan pesantren walisanga dari ketertinggalan.

\section{Daftar Pustaka}

FX Soenaryo dkk., Sejarah Kota Ende (Ende: Dinas Pendidikan dan Kebudayaan, 2006),

Wardana, I Ketut Penataan Nusa Tenggara Pada Masa Kolonial 1915-195o:, Jakarta: Raja Grafindo, 2005.

Munandjar Widyatmika, Sejarah Islam di Nusa Tenggara Timur (Kupang: Pusat Pengembangan Madrasah, 2002)

, Lintasan Sejarah Bumi Cendana (Kupang: Pusat Pengembangan Madrasah, 2002)

Pater Piet Petu. "Sekitar Noa Roja-Nua Ende" (Ende: Sekretariat Panitia Pengumpulan Data Sejarah Berdirinya Kota Ende, tt), Soenaryo dkk., Sejarah Kota Ende (Ende: Dinas Pendidikan dan Kebudayaan, 2006),

Tasuku Sato dan $\mathrm{P}$ Mark Tennien, $A k u$ Terkenang Flores, (Ende: Penerbit Nusa Indah, 2005). h. 43-44. 